\title{
The legalisation of same-sex marriage in Northern Ireland
}

\author{
CONOR MCCORMICK
}

Queen's University Belfast

THOMAS STEWART

Inn of Court of Northern Ireland

\begin{abstract}
The saga which led to the legalisation of same-sex marriage in Northern Ireland offers some important lessons about the processes of law-making for that jurisdiction, together with broader lessons about how the European Convention on Human Rights could be applied in strategic litigation elsewhere. This commentary analyses four episodes in that saga. It begins by evaluating several failed attempts to achieve legalisation at the Northern Ireland Assembly, before considering two legal challenges which also failed in the High Court of Northern Ireland. The developments which eventually led to legal change through the Parliament of the UK are assessed thereafter, followed by an appraisal of the most significant legal features in a set of judgments banded down by the Court of Appeal in Northern Ireland shortly afterwards. It is concluded, in particular, that lessons in connection with bow petitions of concern are deployed in the devolved legislature, as well as lessons about how the probibition on discrimination contained in Article 14 of the Convention has been interpreted, are deserving of wider circulation and appreciation among LGBT rights campaigners in Northern Ireland and beyond.
\end{abstract}

Keywords: Northern Ireland; same-sex marriage; human rights; LGBT.

\section{Introduction}

$\mathrm{T}$ The UK as a whole now recognises same-sex marriage in the domestic law of its three jurisdictions. This reform was first introduced to England and Wales by way of legislation which passed without serious controversy in $2013,{ }^{1}$ before being introduced to Scotland by way of similar legislation that passed by an even greater parliamentary majority at the devolved level in 2014. ${ }^{2}$ Following a referendum, the Republic of Ireland also changed its law in $2015 .{ }^{3}$ However, harmonising the law of Northern Ireland with these

1 Marriage (Same Sex Couples) Act 2013. See Lynne Featherstone, Equal Ever After (Biteback 2016).

2 Marriage and Civil Partnership (Scotland) Act 2014. See Kenneth McK Norrie, 'Civil partnership in Scotland 2004-14, and beyond' in Nicola Barker and Daniel Monk (eds), From Civil Partnership to Same-Sex Marriage: Interdisciplinary Reflections (Routledge 2015). Norrie records that in the Scottish Parliament the outcome of the final vote on same-sex marriage was 105 in favour to 18 against, which he contrasts with the Third Reading of the Marriage (Same Sex Couples) Bill in the House of Commons, which passed with 366 in favour to 161 against.

3 Marriage Act 2015. See Brian Tobin, 'Marriage equality in Ireland: the politico-legal context' in Frances Hamilton and Guido Noto La Diega (eds), Same-sex Relationships, Law and Social Change (Routledge 2020). 
neighbouring jurisdictions was a prolonged enterprise, such that regulations providing for same-sex marriages there were not commenced until 13 January 2020.4

Within the Council of Europe, the UK is now one of 16 out of 47 member states to provide for full legal recognition of same-sex marriages. Those 16 states fall predictably onto the Western side of the map, however, with most Central and Eastern member states refusing to recognise same-sex relationships even by way of civil partnerships and similar alternatives to marriage. ${ }^{5}$ The prolonged process of legalisation in Northern Ireland is likely to be of interest to law reform activists in those member states where traditional familial paradigms still prevail over the campaign for LGBT rights, ${ }^{6}$ not least because social attitudes in Northern Ireland have long been characterised by similar strands of social conservatism. ${ }^{7}$

Indeed, this commentary seeks to outline four significant episodes in the saga which led to the legalisation of same-sex marriage in Northern Ireland for two related reasons. First, it is submitted that they offer general lessons about the processes for law-making in Northern Ireland. Second, it is suggested that they can contribute meaningfully to wider debates about the appropriate interpretation of the right to respect for private and family life (Article 8), the right to marry (Article 12) and, above all, the prohibition on discrimination (Article 14 and Protocol 12) $)^{8}$ under the European Convention on Human Rights (ECHR). The episodes we have identified to this end are outlined chronologically in each of the next four segments of this commentary, followed by a number of summative observations about the saga in its entirety.

\section{Episode 1: the Northern Ireland Assembly}

Between 2012 and 2015, five successive debates and votes on the question of same-sex marriage were held in the Northern Ireland Assembly. Although the last of these, in November 2015, saw a majority of voting Members of the Legislative Assembly (MLAs) do so in favour of legislating for same sex marriage in Northern Ireland, this vote, like the four before it, was subject to the special cross-community support arrangements necessitated by a petition of concern. ${ }^{9}$ When deployed by members of the Democratic Unionist Party (DUP) on each of the five occasions noted, this mechanism had the effect of requiring either 'parallel consent' or a 'weighted majority' before the associated measures

4 Marriage (Same-sex Couples) and Civil Partnership (Opposite-sex Couples) (Northern Ireland) Regulations 2019. See 'Episode 3' below.

5 For an analysis of related phenomena when viewed from the perspective of the EU, see Richard C M Mole, 'Nationalism and homophobia in Central and Eastern Europe' in Koen Slootmaeckers, Heleen Touquet and Peter Vermeersch (eds), The EU Enlargement and Gay Politics: The Impact of Eastern Enlargement on Rights, Activism and Prejudice (Palgrave Macmillan 2016).

6 It is acknowledged that some feminist and LGBT activists do not regard same-sex marriage as a particularly desirable paradigm either. Barker, for instance, suggests that it 'makes lesbians and gays complicit in the labelling of casual sexual encounters as not responsible' and that 'it forecloses more imaginative kinship possibilities that move away from the privatized, nuclear family model'. See Nicola Barker, Not the Marrying Kind: A Feminist Critique of Same-Sex Marriage (Palgrave Macmillan 2012) 15. Also see Ryan Conrad (ed), Against Equality: Queer Critiques of Gay Marriage (Against Equality Publishing 2010).

7 See Frank Cranmer and Sharon Thompson, 'Marriage and civil partnership in Northern Ireland: a changing legal landscape' (2018) 30 Child and Family Law Quarterly 301.

8 Article 14 prohibits discrimination in 'the enjoyment of rights set forth in the Convention', whereas Protocol 12 provides for a general prohibition of discrimination in 'the enjoyment of any right set forth by law'. Protocol 12 has not been signed or ratified by the UK, but its interpretation is significant elsewhere.

$9 \quad$ Northern Ireland Act 1998, section 42. 
could have advanced any further on the legislative agenda of the Assembly. ${ }^{10}$ These political manoeuvres did not take place without some constitutional controversy, however, since the petition of concern had been conceptualised as a mechanism intended 'to manage divisive issues relating to nationalist or unionist culture and political identity, the institutions set up under the [Belfast (Good Friday)] Agreement or the legacy of the conflict'. ${ }^{11}$ As such, the following overview of the five Assembly debates on same-sex marriage should be read with this conceptualisation of the petition of concern firmly in mind.

The first vote, which was defeated by 50 votes to 45 in October 2012, related to a short motion calling on the relevant Minister to 'introduce legislation' that would give effect to the belief that same-sex couples 'should have the right to marry in the eyes of the State'. ${ }^{12}$ In opening the Assembly debate on this motion, the leader of the local Green Party at the time, Steven Agnew MLA, chose to frame his first submissions in the language of 'religious freedom'. ${ }^{13} \mathrm{Mr}$ Agnew referred in particular to 'devout Christian' couples of the same sex, who, due to the constraints of the Civil Partnership Act 2004, could not incorporate religious expression into any aspect of their ceremonies. ${ }^{14}$ The arguments made by MLAs opposed to the 2012 motion were several and varied, but it suffices for our purposes to note that the opposition fell into three broad themes. First, it was suggested that the redefinition of marriage to encompass same-sex relations would represent the thin end of an ideological wedge. The possibility of the Assembly someday legislating for polygamous marriages, for instance, was raised more than once by Jim Allister MLA of Traditional Unionist Voice (TUV). ${ }^{15}$ Second, it was argued that the right to a civil partnership was enough to satisfy the human rights obligations of the Assembly arising under the ECHR, and that same-sex marriage was therefore an unnecessary development. Third, concern was expressed in connection with the idea that religious organisations would find themselves subject to human rights litigation were they to refuse the celebration of same-sex marriages in their buildings.

The 2012 vote was followed in the debates of 2013, 2014 and 2015 by three more motions. ${ }^{16}$ Although these motions would have failed on a simple majority basis, a petition of concern had been tabled against each of them as a precautionary measure. ${ }^{17}$ The motion of 2014 was brought by Sinn Féin and referred to the 'other jurisdictions on these islands' 18 that had legislated for same-sex marriage (though, by this year, this could only have referred to other parts of the UK). In April 2015, a further motion tabled by Sinn Féin was introduced in the knowledge that a referendum on whether to amend the Constitution of Ireland 'to permit marriage to be contracted by two persons without distinction as to their sex' would take place the following month. ${ }^{19}$

10 Ibid, section 4(5). The 'parallel consent' method requires the support of a majority of the members voting, a majority of the designated nationalists voting and a majority of the designated unionists voting, whereas the 'weighted majority' method requires the support of 60 per cent of the members voting, 40 per cent of the designated nationalists voting and 40 per cent of the designated unionists voting.

11 Christopher McCrudden et al, 'Why Northern Ireland's institutions need stability' (2016) 51 Government and Opposition 30, 50-51.

12 Northern Ireland Assembly, Official Report (Hansard), 1 October 2012.

13 Ibid.

14 Ibid.

15 Ibid.

16 Northern Ireland Assembly, Official Report (Hansard), 29 April 2013; 29 April 2014; 27 April 2015.

17 Standing Order 28 of the Northern Ireland Assembly imposes a procedural requirement of advance notice where MLAs wish to present a petition of concern to the Speaker.

18 Northern Ireland Assembly, Official Report (Hansard), 29 April 2014.

19 See Tobin (n 3). 
The final motion on same-sex marriage to come before the Assembly, in November 2015, was tabled on a cross-party basis, with members from Sinn Féin, the Green Party, and the Social Democratic and Labour Party (SDLP) joining forces. ${ }^{20}$ The SDLP leader Colum Eastwood MLA opened this debate by emphasising that it was 'about civil marriage, not religious marriage'. ${ }^{21}$ While this was a noticeable departure from the discourse used by $\mathrm{Mr}$ Agnew to introduce the debate on same-sex marriage three years previously, the change reflected a concerted emphasis on civil marriage in wider campaign efforts throughout the intervening time period. ${ }^{22}$ In contrast, the basis and tenor of the contributions in opposition to the motion were very similar to those put forward on previous occasions. Mr Allister of the TUV, for instance, intervened in the debate to contend once again that same-sex marriage would be but one step on an inexorable path to polygamous marriage. ${ }^{23}$ Notably, the Alliance Party MLA Trevor Lunn - who, as a local councillor, had once voted to block civil partnership ceremonies from taking place on council premises - responded to Mr Allister's 'silly points about polygamy'24 by expressing his reconsidered view that 'marriage is the union of two people who love each other'. ${ }^{25}$ It would become clear that Mr Lunn was not the only MLA to be persuaded by same-sex marriage advocates over the course of time when, following the conclusion of this debate, the November 2015 motion received a majority vote in its favour. Indeed, with the support of 53 members (41 nationalists, 4 unionists and 8 others) over the opposition of 52 members (51 unionists, 1 other), the simple majority which carried that motion would go on to infuse the next four years of activism in connection with the issue of same-sex marriage.

In fact, this episode in the saga which led to the legalisation of same-sex marriage had at least two longer-lasting effects. The first is that it would come to underpin several constitutionally charged debates about the way in which petitions of concern could damage the democratic credentials of the Assembly. While it is true that several criticisms of the petition of concern are 'overstated or misplaced' when viewed in light of the consociational system of government applicable to Northern Ireland, ${ }^{26}$ it is also acknowledged that the procedure is open to abuse where it is 'used to block decisions which have nothing to do with community-specific nationalist or unionist interests' ${ }^{27}$ Given that community-specific considerations of this kind were noticeably absent from contributions to the Assembly debate in November 2015, several onlookers have interpreted this as a constitutionally unjustified abuse of the device. ${ }^{28}$ Indeed, it is likely that this episode played an influential part in the reforms envisaged by the 'New Decade,

20 Northern Ireland Assembly, Official Report (Hansard), 2 November 2015.

21 Ibid.

22 A leading organisation behind the same-sex marriage movement called Love Equality, for example, defined itself as 'a campaign led by a consortium of organisations within Northern Ireland who are campaigning for the introduction of legislation in Northern Ireland for equal civil marriage for same sex couples'. See $<$ https://loveequalityni.org/faqs/ $>$. Emphasis added.

23 Northern Ireland Assembly, Official Report (Hansard), 2 November 2015.

24 Ibid.

25 Ibid.

26 See Rupert Taylor (ed), Consociational Theory: McGarry and O'Leary and the Northern Ireland Conflict (Routledge 2011).

27 McCrudden et al (n 11) 51.

28 See, for example, John McVey, Reforming the Petition of Concern: From 'Concern' to Full Citizenship (NIPSA 2019$) 4$. 
New Approach' deal reached in January 2020, which included an agreement that use of the petition of concern 'should be reduced, and returned to its original purpose'. ${ }^{29}$

The second longer-lasting effect of this episode is that the Assembly has been prevented from deliberating on any of the details in connection with the legislation drafted in order to bring about same-sex marriage in Northern Ireland. In other words, the use of a 'pseudo-petition of concern'30 has meant that the legislation later produced elsewhere to provide for same-sex marriage was deprived of input from the array of democratic representatives elected to the Assembly, whether in the plenary or the committee stages of the legislative process that would likely have followed the successful motion were it not for the requirement of cross-community support.

\section{Episode 2: the High Court of Northern Ireland}

Shortly after the legislative developments described above, two legal challenges were taken to the High Court of Northern Ireland in an effort to legalise same-sex marriage by reference to the evolutive human rights standards protected by the ECHR and given effect by the Human Rights Act 1998. Constitutional rights protected by the common law, such as the right to equality, ${ }^{31}$ were not pressed in any of the proceedings.

The first case was initiated by an anonymised applicant known as $X$ by way of a petition to O'Hara $J$ in the Family Division. ${ }^{32}$ Funded in part by the Public Interest Litigation Support Project, this challenge centred on a gay man who, after marrying his husband in London, sought a declaration recognising that his marriage was valid and subsisting under the law of Northern Ireland. ${ }^{33}$ Given that legislation passed by the UK Parliament had provided that, under the law of Northern Ireland, 'a marriage of a same sex couple under the law of England and Wales is to be treated as a civil partnership formed under the law of England and Wales (and accordingly, the spouses are to be treated as civil partners)', 34 the court was effectively asked to interpret those provisions purposively in order to render them compliant with certain rights protected by the Human Rights Act 1998, or to make a declaration of incompatibility under that Act.

Following a somewhat cursory examination of the Strasbourg case law on Articles 8 and 12 of the ECHR, ${ }^{35}$ the court decided that there was no basis for holding that there existed an obligation to provide for same-sex marriage under either of those rights. Moreover, the learned judge considered himself barred from adopting a more progressive domestic interpretation of the rights engaged by the case on account of higher court

29 New Decade, New Approach (January 2020) paragraph 9. Also see the ruling of the Court of Appeal in Re Close's (Grainne) \& Others' Applications [2020] NICA 20 as set out under 'Episode 4' below.

30 McCrudden et al (n 11) 51.

31 See Colm O'Cinneide, 'Equality: a core common law principle, or “mere” rationality?' in Mark Elliott and Kirsty Hughes (eds), Common Law Constitutional Rights (Hart Publishing 2020). Also see Brice Dickson, 'Common law constitutional rights at the devolved level', in the same volume.

32 X's Petition [2017] NIFam 12.

33 O'Hara $J$ held at [15] that the right to a petition of this kind was provided by Article 31 of the Matrimonial and Family Proceedings (Northern Ireland) Order 1989, notwithstanding several jurisdictional objections raised by the relevant department and by the Attorney General for Northern Ireland.

34 Marriage (Same Sex Couples) Act 2013, schedule 2(1), paragraph 2(1).

35 Article 9, the right to freedom of thought, conscience and religion, was also raised in argument, but the court did not believe that it merited a separate analysis. Article 14 was likewise raised in argument, but it was not so much as addressed in the judgment of the court. For a more thorough analysis of the Strasbourg case law as it stood around this time, see Helen Fenwick, 'Same sex unions at the Strasbourg Court in a divided Europe: driving forward reform or protecting the court's authority via consensus analysis?' (2016) 3 European Human Rights Law Review 249. 
precedents suggesting that he could go no further than Strasbourg. One of the present authors has argued that, on the contrary, 'the future trajectory of Strasbourg jurisprudence on this issue is less than certain' and that 'it is within the powers of the senior judiciary to establish higher standards of human rights' than those enunciated at Strasbourg. ${ }^{36}$ This latter viewpoint, in particular, is supported by several academic studies on the 'mirror principle' (in) famously delineated by the late Lord Bingham in R (Ullah) $v$ Special Adjudicator. ${ }^{37}$ Indeed, the clear finding that emerges from such studies is that 'domestic courts (and authorities, more generally) are not only allowed to go beyond Strasbourg jurisprudence, but are even expected to do so' in certain circumstances. ${ }^{38}$ Some of the most recent research into this issue suggests that there are in fact at least six routes 'which might allow a judge to avert Strasbourg authority', 39 and highlights that a number of those routes were recently affirmed by the UK Supreme Court in Hallam. ${ }^{40}$ In that case, the Supreme Court chose to follow a domestic precedent notwithstanding conflicting Strasbourg case law, but, as Graham has pointed out, some of the justices involved in the decision also felt able to justify a departure from clear, constant Strasbourg case law' on the ground that they simply disagreed strongly with it. ${ }^{41}$ These studies, like the case law underpinning them, confirm beyond doubt that the interpretation of Ullah adopted by O'Hara J was highly contestable.

Before turning to significant developments which preceded the Court of Appeal's judgments, X's Petition must be distinguished from the separate High Court case decided alongside it in August 2017. The second case was initiated by a lesbian couple (Grainne Close and Shannon Sickles) and a gay couple (Christopher and Henry Flanagan-Kane) through an application for judicial review in the Queen's Bench Division, ${ }^{42}$ though it was heard together with $X$ 's Petition before O'Hara J. Both couples were lawfully registered as civil partners in Northern Ireland. ${ }^{43}$ Funded primarily by way of a personalised crowdfunding campaign, their challenge initially fastened upon the use of a petition of concern to obstruct the legalisation of same-sex marriage at the Northern Ireland Assembly. However, the fifth Assembly vote on this issue was worded in a way which called on the Northern Ireland Executive 'to table legislation to allow for same-sex marriage'. ${ }^{44}$ As such, the motion in question did not carry any legislative weight in its own right, which is why, we suspect, 'that part of the case was not pursued'. ${ }^{45}$

Instead, the applicants in Close mounted a direct challenge against Article 6(6)(e) of the Marriage (Northern Ireland) Order 2003, which provides that, if both parties to a proposed marriage ceremony are of the same sex, that fact will constitute a 'legal impediment to marriage', meaning the Registrar General must take all reasonable steps to

36 Conor McCormick, 'Queerying petition X' (Irish Legal News, 25 August 2017)

$<$ https://www.irishlegal.com/article/ni-blog-queerying-petition-x>. Also see the text at nn 75-80 below.

37 [2004] UKHL 26; [2004] 2 AC 323 [20].

38 Nuno Ferreira, 'The Supreme Court in a final push to go beyond Strasbourg' [2015] Public Law 367, 369. Also see: Harry Woolf et al, De Smith's Judicial Review 8th edn (Sweet \& Maxwell 2018) 734-737.

39 Lewis Graham, 'Hallam v Secretary of State: under what circumstances can the Supreme Court depart from Strasbourg authority?’ (UK Constitutional Law Association Blog, 4 February 2019)

<https://ukconstitutionallaw.org/2019/02/04/lewis-graham-hallam-v-secretary-of-state-under-whatcircumstances-can-the-supreme-court-depart-from-strasbourg-authority/ $>$.

40 R (Hallam) v Secretary of State for Justice [2019] UKSC 2, [2020] AC 279.

41 Graham (n 39).

42 Close's (Grainne) \& Others' Applications [2017] NIQB 79.

43 Under the Civil Partnership Regulations (Northern Ireland) 2005.

44 Northern Ireland Assembly, Official Report (Hansard), 2 November 2015. Also see the text at (n 20) above. 
ensure such a marriage does not take place. O'Hara J dismissed the application for reasons largely indistinguishable from those underpinning the dismissal of $X$ 's Petition, though the court did express its interpretation of the Strasbourg case law in more emphatic terms. It was stated, for instance, that, even if it could be accepted that there was an international trend 'moving towards recognition of same sex marriage in more and more countries', there was 'no sign whatever of the Strasbourg Court moving in that direction'. ${ }^{46}$ These assessments are difficult to reconcile with a close reading of the case law, however, given that two Strasbourg judges had in fact highlighted in June 2016 that 'things may change' in so far as the court accords deference to the member states in deciding whether to legalise same-sex marriage. ${ }^{47}$

\section{Episode 3: the Parliament of the UK}

The institutions of devolved government for Northern Ireland came to a standstill in January $2017,{ }^{48}$ which meant that same-sex marriage advocates keen on bringing about law reform outside the courts were left with no alternative but to lobby for legislative change at Westminster. However, on account of the engrained nature of a constitutional convention providing that the UK Parliament would not normally legislate on devolved matters like marriage without the consent of the devolved legislature, it took some time before Westminster parliamentarians were willing to act.

Indeed, it was not until 27 March 2018 - over a year after the collapse of the devolved institutions - that the Conservative Party's Lord Hayward introduced a Private Member's Bill to the House of Lords 'to make provision for the marriage of same sex couples in Northern Ireland'. ${ }^{49}$ Like the ten-minute-rule Bill introduced by Labour's Conor McGinn MP in the House of Commons the next day, ${ }^{50}$ Lord Hayward's Bill made no further progress. Mr McGinn's speech to the Lower House explained that he had been moved to take action notwithstanding some reluctance to unsettle the devolution framework because it was his view that 'the Assembly being in cold storage should not mean that Northern Ireland remains a cold house for LGBT rights' and because same-sex marriage developments in other parts of the British Isles had left Northern Ireland in an 'anomalous' position. ${ }^{51}$ The DUP released a statement in response to this failed attempt to change the law by way of a Private Member's Bill which expressed respect toward the fact that 'others take a different view on how marriage should be defined' but called for recognition of its 'mandated position' against the change. 52

46 Ibid [15]. Emphasis added.

47 Taddeucci and McCall v Italy App no 51362/09 (30 June 2016), per the Concurring Opinion of Judge Spano, joined by Judge Bianku, citing Schalk and Koph v Austria App no 30141/04 (24 June 2010), paragraph 105.

48 For an explanation of the impasse, which finally ended in January 2020, see Brice Dickson, 'Devolution in Northern Ireland' in Jeffrey Jowell and Colm O'Cinneide, The Changing Constitution 9th edn (Oxford University Press 2019) 261-265.

49 Marriage (Same Sex Couples) (Northern Ireland) Bill [HL] 2017-19; HL Deb 27 March 2018, vol 790.

50 Marriage (Same Sex Couples) (Northern Ireland) (No 2) Bill [HC] 2017-19; HC Deb 28 March 2018, vol 638.

51 Ibid. See nn 1-3. Note, moreover, that same-sex marriage was made lawful in the Isle of Man by the Marriage and Civil Partnership (Amendment) Act 2016; in Guernsey by the Same-Sex Marriage (Guernsey) Law 2016; in Alderney by the Same-Sex Marriage (Alderney) Law 2017; and in Jersey by the Marriage and Civil Status (Amendment No 4) (Jersey) Law 2018. The Same-Sex Marriage (Sark) Law 2019 has since received Royal Assent and came into effect on 23 April 2020.

52 'MP quotes "wise men" in Camlough pubs as "same sex marriage" bill passes first stage' (Armagh i, 28 March 2018) <https://armaghi.com/news/northern-ireland-news/mp-quotes-wise-men-in-camlough-pubsas-same-sex-marriage-bill-passes-first-stage/65511>. 
The Northern Ireland (Executive Formation and Exercise of Functions) Act 2018 directed the Secretary of State to issue certain guidance to senior officers of all the Northern Ireland departments, namely the civil servants who had assumed day-to-day responsibility for the running of devolved government during the political impasse. In particular, the Secretary of State was required by section 4(1)(b) to issue guidance on the 'incompatibility of the human rights of the people of Northern Ireland' with the continued enforcement of the prohibition on same-sex marriage, but the anodyne guidance produced by the Secretary of State did not lead to any substantive changes in practice. ${ }^{53}$ Lord Hayward therefore made a further attempt to change the law in the early months of 2019 by way of an amendment to the Civil Partnerships, Marriages and Deaths (Registration etc) Bill.54 This would have required the Secretary of State to make regulations providing for the introduction of same-sex marriage in Northern Ireland, but Lord Hayward was persuaded to withdraw his amendment in light of issues surrounding its 'phraseology and structure'. 55

By July 2019, Northern Ireland had been without an Assembly and Executive for more than two years. In order to avoid the triggering of an election on account of the time limit on Executive formation set out in the Northern Ireland Act 1998, a Northern Ireland (Executive Formation) Bill was introduced to the Commons on 4 July 2019. The original purpose of the Bill was by then unremarkable: it would extend the ministerial appointment period provided for by the Northern Ireland Act $1998^{56}$ and impose a duty on the then Secretary of State, Julian Smith MP, to report on progress towards the formation of an Executive in Northern Ireland. ${ }^{57}$ When the Bill reached its Committee Stage in the Commons, however, Conor McGinn MP proposed the insertion of a clause which would require the Secretary of State to make regulations providing for same-sex marriage in Northern Ireland unless a Northern Ireland Executive was formed on or before 21 October 2019. The parliamentary debate on this motion was bookended by tributes to the lesbian journalist Lyra McKee, who had been killed in Londonderry three months previously and whose death had been associated with the 'political vacuum' created by the lack of an Executive. ${ }^{58}$ A month after Ms McKee's funeral - which had been attended by senior politicians from both the UK and Ireland - her partner had called on the UK government to legislate for same-sex marriage in Northern Ireland at a rally in Belfast. ${ }^{59} \mathrm{Mr}$ McGinn's amendment passed through the House of Commons comfortably, albeit with the support of only one of the 18 MPs representing Northern Ireland constituencies. ${ }^{60}$ The Bill then sailed through the House of Lords with similar levels of support after further amendments had been inserted to ensure that the regulations would include safeguards for the freedoms of religion and expression.

53 Northern Ireland Office, Guidance Issued Under Section 4 of the Northern Ireland (Executive Formation and Exercise of Functions) Act 2018 (Cm 9749, December 2018) paragraphs 10-12.

54 HL Deb 1 February 2019, vol 795, col 1307.

55 HL Deb 1 March 2019, vol 796, col 414.

56 Clauses 1-2.

57 Clause 3.

58 See, for instance, HC Deb 9 July 2019, vol 663, col 187.

59 Henry McDonald, 'Lyra McKee's partner challenged UK government on same-sex marriage' (The Guardian, 18 May 2019) <https://www.theguardian.com/society/2019/may/18/lyra-mckee-partner-challenges-ukgovernment-on-same-sex-marriage-sara-canning-northern-ireland $>$.

60 Seven of these MPs belonged to Sinn Féin, however, meaning they did not vote in the division on account of that party's policy of abstentionism. See HC Deb 9 July 2019, vol 663, col 227. 
Following the passage of the Northern Ireland (Executive Formation etc) Act 2019, it was expected that the Secretary of State for Northern Ireland would be placed under a legal duty to extend same-sex marriage to Northern Ireland in the form of regulations to be made on or before 13 January $2020^{61}$ unless an Executive in Northern Ireland was formed on or before 21 October 2019 (in which case the duty would not come into force). ${ }^{62}$ Similar duties to enable civil partnerships for opposite-sex couples and to liberalise the abortion laws applicable in Northern Ireland were included in this legislation, and, though these provisions fall largely outside the scope of this commentary, it should be noted that the latter duty in connection with abortion laws was the main cause of a failed attempt to revive the Assembly on 21 October 2019. This would have prevented all of the Secretary of State's associated duties from coming into effect, but, while the Assembly was successfully recalled on that date by virtue of a petition signed by 31 MLAs (27 DUP, 3 Ulster Unionist, 1 TUV), those who gathered in the Assembly chamber found themselves unable to elect a Speaker in the absence of cross-community support and were thereby prevented from conducting any legislative business. ${ }^{63}$ The statutory deadline for Executive formation expired in due course thereafter, and so the Secretary of State, Julian Smith MP, set about the preparation of regulations to legalise same-sex marriage in accordance with his statutory duty to do so. Then, at last, the Marriage (Same-sex Couples) and Civil Partnership (Opposite-sex Couples) (Northern Ireland) Regulations 2019 came into force on 13 January 2020.

The 2019 Regulations allow same-sex couples to form a civil marriage and permit opposite-sex couples to register a civil partnership, ${ }^{64}$ though, as noted above, the latter provisions are not relevant for the purposes of this paper. It should be emphasised, however, that the regulations also provide for a range of related rights and entitlements for same-sex couples who avail of their new right to form a civil marriage. These related rights and entitlements span, inter alia, ${ }^{65}$ the law on children and families, ${ }^{66}$ the law on gender recognition, ${ }^{67}$ as well as the law on pensions and social security. ${ }^{68}$ In addition to these core components, moreover, there are at least three related features to note about this important instrument. The first is that by prescribing such detailed consequential amendments to various statutes in related areas of law, the possibility of further litigation over the implications of legalising same-sex marriage has been minimised considerably.

The second point to note is that the rights and entitlements afforded to same-sex couples are accompanied by a series of 'protections' for people who may oppose the concept of same-sex marriage in Northern Ireland. In particular, there are provisions which ensure that it is not unlawful discrimination for religious bodies to provide blessings only to same-sex or opposite-sex couples, ${ }^{69}$ as well as provisions which prevent 'any discussion or criticism of marriage which concerns the sex of the parties' from constituting a hate crime per se. ${ }^{70}$

61 Northern Ireland (Executive Formation etc) Act 2019, section 8.

62 Ibid section 13(4).

63 See 'Abortion: NI politicians' bid to halt law changes fails' (BBC News NI, 21 October 2019) $<$ https://www.bbc.co.uk/news/uk-northern-ireland-50115449>.

64 Marriage (Same-sex Couples) and Civil Partnership (Opposite-sex Couples) (Northern Ireland) Regulations 2019, Part 2

65 Ibid Part 10

66 Ibid Part 4.

67 Ibid Part 5.

68 Ibid Parts 6-8.

69 Ibid regulations 133 and 163.

70 Ibid regulation 142. 
The final point to note about this instrument is that, despite the breadth of issues addressed within its 84 pages, it is a non-exhaustive legal framework for same-sex marriage in Northern Ireland. In particular, the instrument does not introduce any provisions permitting religious same-sex marriages. Nor does it enable same-sex couples who have registered as civil partners in Northern Ireland to convert their registered status to a civil marriage (meaning that, in the interim, the only way that such couples can get married is to file for a disingenuous dissolution of their civil partnership). The UK government has, however, consulted on both of these issues with a view towards the introduction of further regulations which will address them in the near future, but in a way which takes 'the views of the people of Northern Ireland' into account. ${ }^{71}$

\section{Episode 4: the Court of Appeal in Northern Ireland}

Although the Court of Appeal had heard arguments in connection with the judgments of O'Hara J in X and Close in March and September of 2018, judgment was reserved on both appeals until April 2020. ${ }^{72}$ As such, the outcome of both cases was met with rather less attention than would have been the case if legalisation had not been achieved in the interim by way of the legislative developments outlined above. For reasons that will be explained briefly hereafter, however, it would be wrong to classify the Court of Appeal's judgments as largely pyrrhic outcomes, both from the perspective of the litigants involved and from the broader perspective of human rights and anti-discrimination lawyers generally. While the Court of Appeal approved O'Hara J's dismissal of the jurisdictional objections levelled against the appellants in each case and dismissed further objections of a similar kind, ${ }^{73}$ the appellate court's approach is otherwise notable for its dissimilarity from the court below in at least three respects. ${ }^{74}$

First, and to its credit, the court engaged in a closer analysis of the Strasbourg case law on Articles 8 and 12 of the ECHR, ${ }^{75}$ including a fleeting reference to the decision in Orlandi $v$ Italy, ${ }^{76}$ which was handed down after O'Hara J delivered his judgments at first instance. Like O'Hara J, however, the Court of Appeal did not acknowledge an increase in the number of dissenting views on the Strasbourg Court. Nor did it place any particular weight on the tendency of Strasbourg jurisprudence to follow international trends (which are distinguishable from consensuses) in domestic state practices. ${ }^{77}$ It is particularly

71 Northern Ireland Office, Same-sex Religious Marriage in Northern Ireland: Government Consultation (20 January 2020); Northern Ireland Office, Marriage and Civil Partnership - Conversion Entitlements in Northern Ireland: Government Consultation (20 January 2020).

72 Re Close's (Grainne) \& Others' Applications [2020] NICA 20 (Morgan LCJ, Stephens and Treacy LJJ); Re X's Petition [2020] NICA 21 (Morgan LCJ, Stephens and Deeny LJJ).

73 Re Close's (Grainne) \& Others' Applications [2020] NICA 20 [15]-[26]; Re X's Petition [2020] NICA 21 [10]-[13].

74 It is observed that the Court of Appeal has also substantially reframed the analytical framework adopted by justices of the High Court in other recent cases. For a very high-profile example, compare Buick's Application [2018] NIQB (Keegan J) with Re Buick's Application [2018] NICA 26 (Morgan LCJ, Stephens and Treacy LJJ).

75 Re Close's (Grainne) \& Others' Applications [2020] NICA 20 [27]-[39]; Re X's Petition [2020] NICA 21 [19].

76 App no 26431/12 (14 December 2017). For a persuasive analysis of the shortcomings in this decision, especially when compared to the decision of the Court of Justice of the European Union in Case C-673/16 Coman \& Others v Inspectoratul General pentru Imigrări [2018] ECLI:EU:C:2018:385, see Guido Noto La Diega, 'The European approach to recognising, downgrading, and erasing same-sex marriages celebrated abroad' in Hamilton and Noto La Diega (n 3).

77 See, in particular, the Separate and Joint Dissenting Opinion of of Judges Sajó, Keller and Lemmens in Hämäläinen v Finland (App 37359/09) 16 July 2014 [GC]. Also see David Harris et al, Harris, O’Boyle and Warbrick: Law of the European Convention on Human Rights (Oxford University Press 2018) 741, where the authors agree that it can be supposed that Article 12 will in due course be interpreted as requiring [samesex marriages]'. 
regrettable that the Court of Appeal did not engage with the possibility of a 'right to remain married' being read into Article 12, as Strasbourg judges Sajó, Keller and Lemmens have suggested, given that further Strasbourg judges have since emphasised that the interpretation of Article 12 'is not static' and because the dignity of the couple in X's Petition would have benefited so clearly from such an incremental interpretation at common law. ${ }^{78}$ The court was also much more engaged with developments in the domestic jurisprudence on its ability to interpret UK human rights in a manner which would go beyond the current interpretations delineated by Strasbourg. Referring to guidance recently reiterated by the UK Supreme Court, ${ }^{79}$ however, it chose to align itself with Lord Mance's rather conservative approach to this matter and thereby eschewed the more liberal approach that has been commended by Lord Kerr and others. ${ }^{80}$

The second way in which the Court of Appeal's approach differed from the court below relates to the most significant aspect of its judgments, namely the invocation and application of Article 14 of the ECHR (the substance of which was not addressed at all by O'Hara J and therefore formed the implied basis of the Court of Appeal's decision to overturn his judgments). Whereas O'Hara J, having found no violation of Article 8 or 12, ended his analysis and application of the ECHR there, the Court of Appeal prudently went on to explore whether Article 14 was infringed in its own right. This step in the analysis of the court is, of course, entirely consistent with Strasbourg case law which, while respecting the 'parasitic' nature of Article 14,81 has long held that a violation of Article 14 may exist even where there is no violation of the associated Convention rights which have activated it. ${ }^{82}$ Indeed, leading commentators describe this as the principle 'that a state which goes beyond its obligations under a Convention right should do so in a non-discriminatory way'. 83

Furthermore, in response to submissions from the Attorney General for Northern Ireland suggesting that the discretionary area of judgment doctrine in domestic law should import a 'manifestly without reasonable foundation' test, ${ }^{84}$ so as to preclude members of the judiciary from considering an area of social policy such as same-sex marriage, the Court of Appeal was admirably firm in holding that 'strict scrutiny' is required in discrimination cases involving differences in treatment based upon sexual orientation. ${ }^{85}$ Then, applying the standard test for discrimination arising within the ambit of a Convention right - namely an assessment as to whether persons in relevantly similar situations have been treated differently without a reasonable and objective justification ${ }^{86}$ - the court in Close ruled that 'by the time of the delivery of the first instance judgment

78 See the Concurring Opinion of Judge Mits in Ratzenböck and Seydl v Austria App no 28475/12 (26 October 2017). Also see (n 47) above.

79 Re Close's (Grainne) \& Others' Applications [2020] NICA 20 [40], citing Commissioner of Police of the Metropolis v DSD and Another [2018] UKSC 11, [2019] AC 196 [152]-[153].

80 For an overview of the different philosophies on this issue, see Brice Dickson, Human Rights and the United Kingdom Supreme Court (Oxford University Press 2013) 39-43. Also see the text at nn 36-41 above.

81 We are persuaded that Article 14 is 'not quite the "parasite" sometimes alleged', however, given that it 'does not derive nourishment' from other ECHR articles without benefiting them reciprocally. See Oddny Mjöll Arnardóttir, 'Discrimination as a magnifying lens: scope and ambit under Article 14 and Protocol No 12' in Eva Brems and Janneke Gerrards (eds), Shaping Rights in the ECHR (Cambridge University Press 2015) 347.

82 Belgian Linguistics App no 1474/62 and others (23 July 1968).

83 Harris et al (n 77) 768.

84 For a compelling critique of this test, see Jed Meers, 'Problems with the "manifestly without reasonable foundation” test' (2020) 27 Journal of Social Security Law 12.

85 Re Close's (Grainne) \& Others' Applications [2020] NICA 20 [43]-[45].

86 See, for example, Kafkaris v Cyprus App no 21906/04 (12 February 2008) [GC]. 
in this case in August 2017 ... the absence of same-sex marriage in this jurisdiction discriminated against same-sex couples' ${ }^{87}$

Importantly, the Court of Appeal's view on the justifiability of the prohibition on same-sex marriage was heavily influenced by temporal developments. It was emphasised that the balance between 'the legitimate aim of preserving the established nature of marriage 88 and the rights of same-sex couples under Article 14 only became unfair, in the court's view, following reforms to the law in Scotland and Ireland when coupled with the collapse of the devolved institutions of government in Northern Ireland. On the significance of the former, the court explained that there 'are strong ties of kinship and friendship between many people in Northern Ireland and those countries' and that 'people look to them as the source of their identity and culture' to some extent, ${ }^{89}$ while on the significance of the latter it said that adherence to traditional understandings about the division of competences within the devolution framework could not justify any continued interference with the rights of same-sex couples. ${ }^{90}$

Moreover, the judgment of the court in X's Petition placed a somewhat artificial emphasis on the date of the first instance judgment, namely August 2017, in that the court refused to hold that there was further discrimination against the petitioner at any point prior to that date. ${ }^{91}$ While this could be criticised for curtailing the legal duration of the unlawful discrimination suffered by the couple involved, given that the last of the most relevant changes taken into account by the court had occurred by January 2017 (namely the collapse of the devolved institutions), it was a successful appeal nonetheless when viewed from August 2017 onward. With that said, it should be noted that the court did not accept that $X$ was to be compared with same-sex couples whose marriage was not converted to a civil partnership on account of their choice to continue living in England and Wales. Instead, it regarded 'the true comparator' in X's Petition to be 'between those same sex couples who married in England and Wales and those heterosexual couples who did likewise. ${ }^{92}$ The appellants in $X$ and Close were both vindicated by the court in any event, however, given that the judgments in their favour will presumably mean that they do not carry responsibility for legal costs and that they are entitled to claim damages for the unlawful discrimination that they have unjustifiably suffered.

The final way in which the Court of Appeal's judgment differed from the court below arises from its decision to resurrect arguments ex propria motu in connection with the legality of Northern Ireland MLAs tabling a petition of concern against 'matters seeking to advance, promote and protect human rights'. ${ }^{93}$ Recalling that this device had been used to obstruct an otherwise successful motion calling for the legalisation of same-sex marriage, and that the 'statutory purpose of the petition of concern mechanism was to ensure protection for the traditions of both unionist and nationalist communities', the court cautioned that 'enhanced' judicial scrutiny will be required where the device is 'utilised to defeat the will of the Assembly on an issue dealing with a difference of treatment on the grounds of sexual orientation'. ${ }^{94}$ Together with its binding invocation

87 Re Close's (Grainne) \& Others' Applications [2020] NICA 20 [58].

88 Ibid [51]-[52].

89 Ibid [55].

90 Ibid [56]-[57].

91 Re X's Petition [2020] NICA 21 [18].

92 Ibid [25].

93 Re Close's (Grainne) \& Others' Applications [2020] NICA 20 [3]-[4].

94 Ibid [54]. 
and application of Article 14, these obiter dicta will surely be interpreted as a signal that the Court of Appeal can be relied upon to enforce the principles of human rights and equality with independence and rigour if called upon to do so by the people of Northern Ireland in years ahead.

\section{Conclusion}

The saga which led to the legalisation of same-sex marriage in Northern Ireland is complex and, to a certain extent, incomplete. In this commentary, we have limited our analysis to four significant episodes in that saga and critically evaluated each of those episodes through a predominantly legal lens. As such, we wish to acknowledge that there remains considerable scope for further research into the socio-political forces involved in the saga, together with continued research into the long-term implications of the institutional developments concerned. ${ }^{95}$

With that said, in so far as the legal analyses that have been conducted in this paper go, we consider two central findings worthy of emphasis by way of conclusion. The first is that, should the recently restored Northern Ireland Assembly wish to legislate in the area of LGBT rights in the future, it is likely to be constitutionally problematic for a petition of concern to be used to interfere with any business of that sort. This is a consequence of the fact that the 'New Decade, New Approach' deal reached in January 2020 contained a firm political agreement to return the device to its original purpose, ${ }^{96}$ together with the fact that the Court of Appeal has warned that enhanced judicial scrutiny will be applied in the event that a petition of concern is used to obstruct proceedings dealing with a difference of treatment on the grounds of sexual orientation. This is not to say that proposals in connection with LGBT rights are likely to pass all of the relevant stages required by the normal legislative process, of course, only that, because any attempt to use a petition of concern to block such issues from consideration would probably be inconsistent with the original purpose of the device, such an attempt is likely to be challengeable in a range of forums on that basis.

The second finding that ought to be underscored is in connection with the Court of Appeal's novel approach to the invocation and application of Article 14 of the ECHR. The general approach in litigation seeking to have a human right to same-sex marriage recognised under the ECHR, or at least a right to remain married where a member state has recognised a same-sex relationship in that way, has been to invoke Articles 8 and 12 (and sometimes 9) both alone and in conjunction with Article 14. ${ }^{97}$ Given that the European Court of Human Rights has so far refused to recognise any such right framed in this way - though there is certainly cause to suspect that its position will change - it may be recalled that the Court of Appeal felt itself unable to depart from that line of Strasbourg jurisprudence. By ruling that the absence of a right to same-sex marriage was incompatible with Article 14 in its own right, however, the Court of Appeal nimbly avoided any inconsistency with the Strasbourg jurisprudence and, in so doing, devised an original form of legal argument that is at least theoretically capable of transplantation to

95 For some early examples of the interesting research emanating from other disciplines and perspectives, see Cevat G Aksoy et al, 'Do laws shape attitudes? Evidence from same-sex relationship recognition policies in Europe’ (2020) 124 European Economic Review 103399; Bernadette C Hayes and John Nagle, 'Ethnonationalism and attitudes towards same-sex marriage and abortion in Northern Ireland' (2019) 40 International Political Science Review 455; Jocelyn Evans and Jonathan Tonge, 'Partisan and religious drivers of moral conservatism: same-sex marriage and abortion in Northern Ireland' (2018) 24 Party Politics 335.

96 For a definition of its original purpose, see the text at $\mathrm{n} 11$ above.

97 See, in addition to the references provided under 'Episode 2' and 'Episode 4' above, Paul Johnson, Homosexuality and the European Court of Human Rights (Routledge 2012) chapter 6. 
other member states. The reasoning of the court was heavily reliant on contextual considerations, of course, but its cognisance of changes in the state practices of neighbouring jurisdictions could be capable of influencing the reasoning of the courts in some member states on the margins of Western Europe where same-sex marriage remains unlawful. While academics like Masuma Shahid have speculated that the ambit of Article 14 could be interpreted in a manner expansive enough to deal with equal marriage rights in this way, ${ }^{98}$ the Court of Appeal in Northern Ireland appears to be the first judicial body to have formulated such a domestic basis for the right to same-sex marriage in practice. This much demonstrates that the full significance of the saga which led to the legalisation of same-sex marriage in Northern Ireland is perhaps yet to be seen.

98 Masuma Shahid, 'The right to same-sex marriage: assessing the European Court of Human Rights' consensus-based analysis in recent judgments concerning equal marriage rights' (2017) 10 Erasmus Law Review 184, 197. 